\title{
A tribute to Albert Lillehammer (1930-1992) and his scientific work
}

\author{
John E. Brittain
}

Freshwater Ecology \& Inland Fisheries Laboratory, Zoological Museum, University of Oslo, Sars gate 1, 0562 Oslo, Norway.

It was with great shock that we received notification of the untimely death of our good friend and colleague $\mathrm{D}^{\mathrm{r}}$ Albert Lillehammer. He had suffered a fatal heart attack in Stockholm on his return from giving a guest at the University of Umeå. In his scientific career, which spanned some 30 years, he had gained an international reputation for his work on stonefly taxonomy and ecology as well as in the field of regulated rivers research. Throughout his scientific career he worked at the Zoological Museum of the University of Oslo, progressing to this present position of Senior Curator of Entomology.

Albert Lillehammer was a pioneer in regulated rivers research. He was a founder member of the permanent committee responsible for arranging the international symposia on regulated streams. His active participation in research on regulated rivers, both nationally and internationally led to the Second International Symposium on Regulated Streams being arranged in Oslo in 1982. He chaired the organizing committee and also co-edited the proceedings, " Regulated Rivers ». In his M.Sc. thesis from 1964 he had compared a regulated river with an unregulated one, the Suldalslågen. The Suldalslågen was subsequently regulated and this particular Norwegian river and its salmon population always had a special significance for him. He frequently returned there to work and at the time of his death he was occupied more than ever with research on this salmon river in south-western Norway, not far from the town where he was born.

However, for many scientists Albert Lillehammer is probably better known as a skilled worker on stoneflies. In fact he took his doctorate in 1975 on the systematics, distribution and ecology of Norwegian stoneflies. He made a major contribution to our knowledge of stonefly life history strategies and his laboratory studies of egg and nymphal development are widely recognized. He was particularly interested in the variation in the morphological characters used in taxonomy and in 1988 he published his major taxonomic work, «The Stoneflies (Plecoptera) of Fennoscandia and Denmark ». This work will serve as an excellent key and information source on the region's stonefly fauna for many years to come.

His vision was to build up a strong scientific group in Norway in the field of river ecology. Some of it this was fulfilled, but much still remains for his colleagues and friends to complete. Albert will be sadly missed, both for his scientific achievements and for his pleasant and friendly nature. The scientic communitry, and in particular freshwater biology, has lost a valuable member.

\section{ALBERT LILLEHAMMER - BIBLIOGRAPHY}

Lillehammer A. 1964. - Studies of the fauna of the River Suldalslågen, West Norway. 1. Evaluation of methods for benthic studies. Norsk ent. Tidsskr. 12 : 224-234. In Norwegian, English summary.

Lillehammer A. 1965. - New records of Capnia bifrons (Newman) at Tynset in Hedmark (Plecoptera, Capniidae). Norsk ent. Tidsskr., 13 : 92-96.

Lillehammer A. 1965. - Investigations regarding the Plecoptera fauna in Rogaland, West Norway. 1. Inner Region (Ryfylke), lowland. Norsk ent. Tidsskr., 13 : 101-118. In Norwegian, English summary. 
Lillehammer A. 1965. - Capture of Capnia bifrons (Newman) at Øverland in Bærum (Plecoptera, Capniidae). Norsk ent. Tidsskr., 12 : 47-51.

Lillehammer A. 1966. - Bottom fauna investigations in a Norwegian river. The influence of ecological factors. Nytt Mag. Zool., 13 : 10-29.

Lillehammer A. 1968. - Some finds of stoneflies, Plecoptera. Norsk ent. Tidsskr., 15 : 83-84.

Lillehammer A. 1972. - Notes on the stonefly Capnia vidua Klapalék from Fennoscandia. Norsk ent. Tidsskr., 19 : 153-156.

Lillehammer A. 1972. - Notes on the stonefly Nemoura sahlbergi Morton, with a description of the nymph. Norsk ent. Tidsskr., 19 : 157-159.

Lillehammer A. 1972. - A new species of the genus Nemoura (Plecoptera) from Finnmark, North Norway. Norsk ent. Tidsskr., 19 : 161-163.

Lillehammer A. 1973. - An investigation of the food of one to four month old Salmon fry (Salmo salar L.) in the river Suldalslågen, West Norway. Norw. J. Zool., 21 : 17-24.

Lillehammer A. 1973. - Notes on the feeding relationships of Trout (Salmo trutta L.) and Salmon (Salmo salar L.) in the River Suldalslågen, West Norway. Norw. J. Zool., 21 : 25-28.

Lillehammer A. 1973. - The nymph of Capnopsis schilleri (Rostock) 1892. Notes on its morphology and emergence. Norsk ent. Tidsskr., 20 : 267-268.

Lillehammer A. 1974. - Norwegian stoneflies I. Analysis of the variations in morphological and structural characters used in taxonomy. Norsk. ent. Tidsskr., 21 : 59-107.

Lillehammer A. 1974. - Norwegian stoneflies II. Distribution and relationship to the environment. Norsk ent. Tidsskr., 21 : 195-250.

Lillehammer A. 1975. - Norwegian stoneflies III. Field studies on ecological factors influencing distribution. Norw. J. Ent., 22 : 71-80.

Lillehammer A. 1975. - Norwegian stoneflies IV. Laboratory studies on ecological factors influencing distribution. Norw. J. Ent., 22 : 99-108.

Lillehammer A. 1975. - Norwegian stoneflies V. Variations in morphological characters compared to differences in ecological factors. Norw. J. Ent., 22 : 161-172.

Lillehammer A. 1978. - The Plecoptera of Øvre Heimdalsvatn. Holarct. Ecol., 1 : 232-238.

Aarefjord F., Brittain J.E. \& Lillehammer A. 1978. The benthos of Øvre Heimdalsvatn : Introduction. Holarct. Ecol., 1 : 219-220.

Brittain J.E. \& Lillehammer A. 1978. - The fauna of the exposed zone of Øvre Heimdalsvatn : methods, sampling stations and general.results. Holarct. Ecol., $1: 221-228$.
Lillehammer A. \& Brittain J.E. 1978. - The invertebrate fauna of the streams in Øvre Heimdalen. Holarct. Ecol., $1:$ 271-276.

Larsson P., Lien L., Brittain J.E., Lillehammer A. \& Tangen K. 1978. - The lake ecosystem of Øvre Heimdalsvatn. Holarct. Ecol., 1 : 304-320.

Lillehammer A. \& Saltveit S.J. 1980. - Stream regulation in Norway. In Ward J.V. \& Stanford J.A. (eds). The Ecology of Regulated Streams. Plenum Press, New York, p. 201-213.

Lillehammer A. 1984. - Distribution, seasonal abundance and emergence of stoneflies (Plecoptera) in the Evre Heimdal area of the Norwegian Jotunheimen Mountains. Fauna norv. Ser. B, 31 : 1-7.

Lillehammer A. 1984. - Ecology of the Suldalslágen river in western Norway before its regulation. Fauna norv. Ser. A., 5 : 22-30.

Lillehammer A., Brittain J.E. \& Saltveit S.J. 1984. - Egg development, nymphal growth and distribution of Fennoscandian stoneflies (Plecoptera). Abstract. Annls Limnol., $20: 144$.

Lillehammer A. \& Saltveit S.J. 1984. - The effect of regulation on the aquatic macroinvertebrate fauna of the River Suldalslågen, Western Norway, p. 201-210 in Lillehammer A. \& Saltveit S.J. (eds). Regulated Rivers. University of Oslo Press, Oslo, 540 p.

Brittain J.E., Lillehammer A. \& Bildeng R. 1984. - The impact of a water transfer scheme on the benthic macroinvertebrates of a Norwegian river. p. 189-199 In Lillehammer A. \& Saltveit S.J. (eds). Regulated Rivers. University of Osio Press, Oslo, 540 p.

Brittain J.E., Lillehammer A. \& Saltveit S.J. 1984. - The effect of temperature on intraspecific variation in egg biology and nymphal size in the stonefly, Capnia atra (Plecoptera). J. Anim. Ecol., 53 : 161-169.

Saltveit S.J. \& Lillehammer A. 1984. - Studies on egg development in Fennoscandian Isoperla species (Plecoptera). Annls Limnol., 20 : 91-94.

Skulberg O. \& Lillehammer A. 1984. — Glåma, p. 469-498 In Witton, B.A. (ed.) Ecology of European Rivers. Blackwell, Oxford. 644 p.

Lillehammer A. 1985. - The coexistence of stoneflies in a mountain lake outlet biotope. Aquatic Insects, 7 : 173-187.

Lillehammer A. 1985. - Zoogeographical studies on Fennoscandian stoneflies. J. Biogeogr., $12: 209-221$.

Lillehammer A. 1985. - Temperature influence on egg incubation period and nymphal growth of the stoneflies Leuctra digitata and L. fusca (Plecoptera : Leuctridae). Entomol. Gen., $11: 59-67$.

Lillehammer A. 1985. - Studies of shortwingedness in stoneflies (Plecoptera). Fauna norv. Ser. B., 32 : 58-61.

Lillehammer A. 1985. - Ecology of the regulated river Storelva in western Norway 50 years after regulation. Fauna norv. Ser. A., 6 : 35-41. 
Lillehammer A. 1986. - Taxonomic differences between population of Leuctra hippopus Kempny (Plecoptera) in Norway. Fauna norv. Ser. B., $33: 27-32$.

Lillehammer A. 1986. - Egg development of the stoneflies Siphonoperla burmeisteri (Chloroperlidae) and Dinocras cephalotes (Perlidae). Freshwat. Biol., 16 : 35-39.

Lillehammer A., Johansson M. \& Gislasson G.M. 1986. - Studies on Capnia vidua Klapalek (Capniidae, Plecoptera) populations in Iceland. Fauna norv. Ser. B., $33:$ 93-97.

Lillehammer A. 1986. - The effect of temperature on egg incubation period and nymphal growth of two Nemoura species (Plecoptera) from subarctic Fennoscandia. Aquatic Insects, $8:$ 223-235.

Brittain J.E., Lillehammer A. \& Saltveit S.J. 1986. Intraspecific variation in the nymphal growth rate of the stonefly, Capnia atra (Plecoptera). J. Anim. Ecol., 55 : 1001-1006.

Lillehammer A. 1987. - Intraspecific variation in the biology of eggs and nymphs of Norwegian populations of Leuctra hippopus (Plecoptera). J. Nat. Hist., 21 : 29-41.

Lillehammer A. 1987. - Nymphs of the Fennoscandian Nemoura Latreille nymphs (Nemouridae, Plecoptera), with a key to species. Ent. scand., $17: 511-519$.

Brittain J.E., Lillehammer A. \& Saltveit S.J. 1987. - Stoneflies and river regulation - a review. p. 117-129 In WCraig J.F \& Kemper J.B. (eds). Advances in Regulated Streams Ecology. Plenum Press, New York. $500 \mathrm{p}$.
Lillehammer A. 1987. - Diapause and quiescence in eggs of Systellognatha stonefly species (Plecoptera) occurring in alpine areas of Norway. Annls Limnol., 23 : 179-184.

Brittain J.E. \& Lillehammer A. 1987. - Variability in the rate of egg development of the stonefly, Nemoura cinerea (Plecoptera). Freshwat. Biol., 17 : 565-568.

Lillehammer A. \& Brittain J.E. 1987. - Longitudinal zonation of the benthic invertebrate fauna in the River Glomma, Eastern Norway. Fauna norv. Ser. A., 8 : 1-10.

Lillehammer A. 1987. - Biological and morphological characteristica of marginal population of Capnia atra (Plecoptera) in Suldalslågen, Eastern Norway. Fauna norv. Ser. B., $35: 31-34$.

Lillehammer A. 1988. - Plecoptera Fauna of Fennoscandia and Denmark. Fauna Entomol. scand., 21. E. Brill, Leiden. 163 p.

Lillehammer A. \& Økland B. 1988. - Taxonomy of stonefly eggs of the genus Isoperla (Plecoptera, Perlodidae). Fauna norv. Ser. B., 34 : 121-124.

Lillehammer A., Brittain J.E., Saltveit S.J. \& Nielsen P. 1989. - Egg development, nymphal growth and life cycle strategies in Plecoptera. Holarct. Ecol., 12 : 173-186.

Lillehammer A., Saltveit S.J. \& Brusven M. 1990. - The influence of variable temperatures on the incubation period of stonefly eggs (Plecoptera), p. 377-385 In Alba-Tercedor J. \& Sanchez-Ortega A. (eds). Overview and Strategies of Ephemeroptera and Plecoptera. The Sandhill Crane Press Inc., Gainesville, Florida, USA, 588 p. 